\title{
Asupan Vitamin C dan E dengan SQ-FFQ terhadap Fungsi Paru Perokok dan Non-Perokok
}

\section{Vitamin C and E Intake with SQ-FFQ towards Smokers' and Non-Smokers' Lung Function}

\author{
Siska Rian Pratiwi ${ }^{1 *}$, Amelia Lorensia ${ }^{2}$, Rivan Virlando Suryadinata ${ }^{3}$ \\ ${ }^{1}$ Mahasiswa Program Studi Magister Ilmu Farmasi, Fakultas Farmasi, Universitas Surabaya \\ ${ }^{2}$ Departemen Farmasi-Klinis Komunitas, Fakultas Farmasi, Universitas Surabaya \\ ${ }^{3}$ Departemen Ilmu Kesehatan Masyarakat, Fakultas Kedokteran, Universitas Surabaya \\ (*siskarian@gmail.com)
}

\begin{abstract}
ABSTRAK
Asap rokok merupakan salah satu sumber radikal bebas eksogen yang dapat menyebabkan kerusakan sel yang mengakibatkan penurunan fungsi paru. Vitamin $\mathrm{C}$ dan $\mathrm{E}$ merupakan antioksidan yang dapat menghambat aktivitas senyawa oksidan. Tujuan dari penelitian ini adalah mengetahui perbedaan kondisi fungsi paru, asupan vitamin C, asupan vitamin E pada perokok aktif dan non perokok, serta pengaruh asupan vitamin C dan E terhadap kondisi fungsi paru. Desain penelitian yang digunakan adalah cross sectional. Variabel yang diukur meliputi asupan vitamin C dan E dengan Semi Quantitative-Food Frequency Questionnaire (SQ-FFQ) serta kondisi fungsi paru dengan handheld spirometer. Sampel penelitian ini terdiri dari 63 sampel perokok dan 63 sampel non perokok. Hasil uji menunjukkan fungsi paru dan asupan vitamin $C$ berbeda signifikan $(p=0,00)$, sedangkan asupan vitamin $\mathrm{E}(\mathrm{p}=0,29)$ tidak berbeda signifikan antara perokok aktif dan non perokok. Hasil analisis menunjukkan adanya pengaruh asupan vitamin $\mathrm{C}(\mathrm{p}=0,00 ; \mathrm{r}=0,63)$ dan vitamin $\mathrm{E}(\mathrm{p}=0,015 ; \mathrm{r}=0,22)$ terhadap kondisi fungsi paru. Terdapat perbedaan asupan vitamin $\mathrm{C}$ dan fungsi paru pada perokok dan non perokok, serta adanya pengaruh asupan vitamin $\mathrm{C}$ dan $\mathrm{E}$ terhadap fungsi paru.
\end{abstract}

Kata kunci : Rokok, fungsi paru, vitamin C, vitamin E

\section{ABSTRACT}

Cigarette smoke is one of exogenous free radical source which causes cell damage to make a decrease of lung function happen. Vitamin $C$ and $E$ are antioxidants which can obstruct the activity of oxidant compounds. The purpose of this research was to know the distinction of lung function, Vitamin $C$ and $E$ intake on active and non smoker; the influence of vitamin $C$ and $E$ intake towards the lung function. The research design was cross sectional. The measured variables consisted of Vitamin $C$ and $E$ intake by semi quantitative-food frequency questionnaire (SQ-FFQ) as well as the lung function by handheld spirometer. The sampling of this research consisted of 63 samples of smokers and 63 samples of non-smoker. The test results showed lung function and vitamin C intake was significantly different $(p=0,00)$, while vitamin $E(p=0,29)$ intake did not differ significantly between active smoker and non smoker. The results showed the influence Vitamin $C(p=0,00 ; r=0,63)$ and Vitamin $E(p=0,015 ; r=0,22)$ intake towards the lung function. There are differences in vitamin $C$ and $E$ intake, the lung function of smoker and non smoker; and the influence of Vitamin $C$ and $E$ intake towards the lung function.

Keywords : Cigarette, lung function, vitamin C, vitamin $E$ 


\section{PENDAHULUAN}

Merokok merupakan perilaku umum yang dilakukan oleh penduduk Indonesia dan menjadi penyebab utama terbesar kematian yang sulit dicegah di masyarakat. Jumlah perokok di Indonesia mengalami peningkatan dari tahun ke tahun. Pada tahun 1995 jumlah perokok di Indonesia sebesar $27,2 \%$, meningkat menjadi $34,2 \%$ pada tahun 2007 dan $36,3 \%$ pada tahun 2013 dengan prevalensi $64,9 \%$ laki-laki pada usia lebih dari 15 tahun., Hal ini menempatkan Indonesia berada di urutan keempat di dunia untuk jumlah perokok lakilaki dan menduduki peringkat pertama di negara ASEAN. ${ }^{3}$

Asap rokok merupakan salah satu sumber terbesar radikal bebas eksogen. Radikal bebas adalah senyawa oksigen reaktif yang merupakan senyawa dengan elektron yang tidak berpasangan. Senyawa atau atom tersebut berusaha mencapai keadaan stabil dengan jalan menarik elektron lain sehingga terbentuk radikal baru. ${ }^{4}$ Ghosh dan Ionita tahun 2007 meneliti kandungan radikal bebas dari asap rokok menyatakan dalam satu hembusan asap rokok mengandung $10^{14}-10^{15}$ radikal bebas. ${ }^{5}$ Radikal bebas pada fase gas berumur pendek dan mempengaruhi lebih banyak pada saluran pernafasan atas, oksidan pada fase tar relatif stabil yang dapat membahayakan langsung pada paru-paru. ${ }^{6}$

Radikal bebas yang meningkat pada tubuh perokok menyebabkan turunnya kapasitas paru, dan iritasi pada saluran pernafasan yang mengakibatkan keterbatasan aliran udara. ${ }^{7}$ Gangguan fungsi paru dapat diperiksa menggunakan spirometri dengan mengukur volume ekspirasi paksa dalam 1 detik atau forced expiratory volume in first second $\left(\mathrm{FEV}_{1}\right)$. Penelitian yang dilakukan oleh Adegoke et al., menyatakan adanya penurunan fungsi paru pada perokok dibandingkan dengan non-perokok, ditunjukkan dengan penurunan secara signifikan nilai $\mathrm{FEV}_{1} \cdot{ }^{8}$ Penelitian ini akan melihat kondisi fungsi paru dengan menilai $\mathrm{FEV}_{1}$ dengan menggunakan alat handheld spirometer.

Antioksidan bekerja dengan cara memberikan elektron kepada radikal bebas sehingga dapat menghentikan proses perusakan sel. ${ }^{9}$ Antioksidan akan menetralisir radikal bebas sehingga tidak mempunyai memampuan lagi mengambil elektron dari sel dan DNA. Oleh karena itu, tubuh memerlukan antioksidan yang dapat membantu melin- dungi tubuh dari bahaya yang ditimbulkan oleh radikal bebas maupun senyawa radikal. ${ }^{9} 10$ Tubuh manusia dapat menetralisir radikal bebas apabila jumlahnya tidak berlebihan, dengan mekanisme pertahanan antioksidan endogen. Bila antioksidan endogen tidak mencukupi, tubuh membutuhkan antioksidan dari luar. ${ }^{10,11}$ Cara meningkatkan antioksidan di dalam tubuh diantaranya dengan asupan antioksidan eksogen dari makanan dan suplemen, smoking cessation, dan olahraga. ${ }^{12,13}$

Senyawa pada makanan yang memiliki aktivitas antioksidan diantaranya adalah vitamin C dan vitamin E. ${ }^{14}$ Asupan makanan buah, asam askorbat (vitamin C), tokoferol (vitamin E), dan beta karoten pada perokok terbukti meningkatkan fungsi paru dengan meningkatnya $\mathrm{FEV}_{1}{ }^{15}$ Suatu penelitian yang dilakukan oleh Burns et al. tahun 2007 menunjukkan asupan makanan antioksidan dan mikronutrien antiinflamasi dapat meningkatkan fungsi paru dan mengurangi stres oksidatif. ${ }^{16}$ SQ-FFQ merupakan cara atau metode untuk mengetahui gambaran asupan gizi tertentu selama periode waktu tertentu. Penilaian asupan antioksidan dengan menggunakan SQ-FFQ sebelumnya pernah dilakukan diantaranya oleh Bentley et al., dan Russnes et al. ${ }^{17,18}$ Penelitian terdahulu di Indonesia yang menggunakan SQ-FFQ diantaranya oleh Purnasari et al., dan Tritisari et al. ${ }^{19,20}$ Belum ada penelitian yang menilai asupan antioksidan pada perokok aktif dan non perokok di Indonesia. Berdasarkan hal yang telah diuraikan tersebut, maka peneliti tertarik untuk menilai asupan antioksidan yang terkandung dalam makanan yang dikonsumsi dengan menggunakan SQ-FFQ. Penelitian bertujuan mengetahui perbedaan kondisi fungsi paru, asupan vitamin $C$, asupan vitamin $\mathrm{E}$ pada perokok aktif dan non perokok, serta mengetahui adanya pengaruh asupan vitamin $\mathrm{C}$ dan vitamin E terhadap fungsi paru.

\section{BAHAN DAN METODE}

Penelitian yang dilakukan adalah penelitian observasi analitik dengan desain cross sectional. Lokasi penelitian dilakukan di Surabaya Selatan dengan waktu penelitian dimulai dari bulan Januari-Maret 2018. Populasi kasus dan kontrol pada penelitian ini adalah perokok aktif dan non perokok. Definisi perokok aktif adalah individu yang telah merokok $\geq 100$ batang rokok 
sepanjang hidupnya dan saat ini masih merokok $\geq 1$ batang rokok per hari, sedangkan non perokok adalah individu yang sepanjang hidupnya belum pernah merokok atau mencoba untuk merokok, tetapi $\leq 100$ batang rokok dan sudah tidak merokok lagi selama 30 hari terakhir. ${ }^{17,21,22}$ Sampel penelitian dalam penelitian ini adalah perokok aktif atau non perokok, bersedia mengikuti penelitian, laki-laki berusia 18-40 tahun, memiliki latar belakang SMA, tidak sedang menjalankan diet khusus, dan tidak ada penyakit restriksi atau obstruksi pernafasan. ${ }^{23,24,25}$ Teknik pengambilan sampel pada penelitian ini menggunakan metode purposive sampling. Jumlah sampel pada penelitian ini 126 sampel yang terdiri dari 63 sampel perokok dan 63 sampel non perokok.

Kondisi fungsi paru digambarkan dengan forced expiratory volume in first second $\left(\mathrm{FEV}_{1}\right)$ dalam satuan persen yang diukur dengan menggunakan alat handheld spirometer. Hasil FEV diklasifikasikan menurut American Thoracic Society (ATS)/European Society Respiratory (ERS) berdasarkan tingkat keparahannya, dikategorikan menjadi normal $(>80 \%)$, mild $(>70 \%)$, moderate $(60-79)$, severe $(35-49 \%)$, very severe $(<35 \%){ }^{26}$ Daftar makanan yang masuk kedalam SQ-FFQ merupakan bahan makanan mengandung vitamin C dan E yang diperoleh dari Daftar Komposisi Bahan Makanan Indonesia (DKBM) kemudian dilakukan studi pendahuluan kepada 20 respon- den. Bahan makanan yang tidak pernah atau jarang dikonsumsi dikeluarkan dari daftar. Kuesioner mencakup frekuensi bahan makanan yang dikonsumsi dalam satu hari, satu minggu, satu bulan, atau tidak pernah.

Data asupan makanan sumber vitamin $\mathrm{C}$ dan E selama satu bulan dikumpulkan melalui wawancara menggunakan kuesioner SQ-FFQ dan diolah menggunakan program nutrisurvey 2007. Hasil jumlah asupan vitamin $\mathrm{C}$ dan $\mathrm{E}$ per hari dikelompokkan menjadi cukup dan kurang. Asupan vitamin C dikatakan cukup apabila dikonsumsi lebih dari $90 \mathrm{mg}$ /hari, dan asupan vitamin $\mathrm{E}$ lebih dari $15 \mathrm{mg} /$ hari. ${ }^{27}$ Analisis statistik yang digunakan adalah uji Mann Whitney dengan membandingkan kondisi fungsi paru, asupan vitamin $\mathrm{C}$ dan vitamin E pada perokok dan perokok dengan skala rasio. Untuk mengetahui hubungan antara variabel dependen dan variabel independen dilakukan analisis bivaiat menggunakan korelasi spearman.

\section{HASIL}

Penelitian dilakukan pada 126 sampel yang terdiri dari perokok aktif dan non perokok masingmasing 63 sampel, pengambilan data dilakukan pada bulan Januari-Maret 2018 di Surabaya Selatan. Hasil uji homogenitas pada usia sampel penelitian menunjukkan usia antara kedua kelompok homogen (Tabel 1).

Hasil uji fungsi paru menunjukkan seba-

Tabel 1. Karakteristik Sampel Penelitian

\begin{tabular}{cccc}
\hline \multirow{2}{*}{ Karakteristik } & \multicolumn{2}{c}{ Median \pm SD (tahun) } & \multirow{2}{*}{ Homogenitas } \\
\cline { 2 - 3 } & Perokok Aktif $(\mathrm{n}=63)$ & Non Perokok $(\mathrm{n}=63)$ & \\
\hline Usia (tahun) & $22 \pm 4.61$ & $21 \pm 4.11$ & $\mathrm{p}=\mathbf{0 , 4 7 6}$ \\
\hline
\end{tabular}

Tabel 2. Klasifikasi Hasil Fungsi Paru (FEV1) dan Profil Asupan Vitamin C

\begin{tabular}{lcccc}
\hline \multirow{2}{*}{ Item } & \multicolumn{2}{c}{ Perokok Aktif $(\mathbf{n}=\mathbf{6 3})$} & \multicolumn{2}{c}{ Non Perokok $(\mathbf{n}=\mathbf{6 3})$} \\
\cline { 2 - 5 } & $\mathbf{n}$ & $\mathbf{\%}$ & $\mathbf{n}$ & $\mathbf{\%}$ \\
\hline Kategori Fungsi Paru (\%) & & & & \\
$\quad$ Normal $(>80)$ & 3 & 4,76 & 34 & 53,97 \\
Mild $(>70)$ & 31 & 49,21 & 26 & 41,27 \\
Moderate (60-69) & 21 & 33,33 & 3 & 4,76 \\
Moderately severe (50-59) & 8 & 12,7 & 0 & 0 \\
Severe (35-49) & 0 & 0 & 0 & 0 \\
Very severe (<35) & 0 & 0 & 0 & \\
Kategori AKG & & & & 19,05 \\
$\quad$ Cukup & 1 & 1,58 & 12 & 80,95 \\
Kurang & 62 & 98,41 & 51 &
\end{tabular}


Tabel 3. Hasil Uji Perbedaan Fungsi Paru, Asupan Vitamin C dan E Perokok Aktif dan Non Perokok

\begin{tabular}{cccc}
\hline \multirow{2}{*}{ Jenis } & \multicolumn{2}{c}{ Median \pm SD $(\mathbf{m g} /$ hari) } & \multirow{2}{*}{ Nilai signifikansi } \\
\cline { 2 - 3 } & Perokok Aktif & Non Perokok & \\
\hline FEV1 & $70 \pm 7,14$ & $80 \pm 7,10$ & $\mathrm{p}=0,00^{*}$ \\
Vitamin C & $26.2 \pm 20,31$ & $57 \pm 35,15$ & $\mathrm{p}=0,00^{*}$ \\
Vitamin E & $3,4 \pm 1,48$ & $3,7 \pm 1,88$ & $\mathrm{p}=0,29$ \\
\hline
\end{tabular}

*Berbeda signifikan pada $\mathrm{p}<0,05$

Tabel 4. Hasil Uji Korelasi Asupan Vitamin C dan E terhadap Fungsi Paru

\begin{tabular}{cc}
\hline Asupan & Korelasi terhadap FEV1 \\
\hline Vitamin C & $\mathrm{p}=0,00^{*} ; \mathrm{r}=0,63$ \\
Vitamin E & $\mathrm{p}=0,015^{*} ; \mathrm{r}=0,22$ \\
\hline
\end{tabular}

* Berhubungan signifikan pada $\mathrm{p}<0,05$

nyak $4,76 \%$ sampel perokok aktif masuk dalam kategori normal, 49,21\% masuk dalam kategori mild, sebanyak 33,33\% masuk dalam kategori moderate, dan sebanyak $12,7 \%$ masuk ke dalam kategori moderately severe. Didapatkan pula hasil pada kelompok non perokok sebanyak 53,97\% masuk dalam kategori normal, $41,27 \%$ masuk dalam kategori mild, 4,67\% masuk dalam kategori moderate. Tidak ada satupun sampel dari kelompok perokok maupun non perokok masuk ke dalam kategori severe dan very severe (Tabel 2).

Hasil asupan vitamin $\mathrm{C}$ menunjukkan pada kelompok perokok aktif sebanyak $98,41 \%$ sampel memiliki asupan vitamin $\mathrm{C}$ yang kurang dan $1,58 \%$ telah mendapatkan asupan vitamin $\mathrm{C}$ yang cukup. Kelompok perokok menunjukkan sebanyak $80,95 \%$ mengalami asupan vitamin $\mathrm{C}$ yang kurang dan 19,05\% telah mendapatkan asupan vitamin C yang cukup (Tabel 2). Berdasarkan hasil penelitian, tidak ada satu pun sampel dari kelompok perokok maupun non perokok yang memenuhi angka kecukupan asupan vitamin E yang cukup.

Uji perbedaan kondisi fungsi paru antara perokok aktif dan non perokok diolah dengan menggunakan SPSS 23.00 for windows. Normalitas sebaran diuji dengan kolmogrov-smirnov diperoleh nilai signifikansi kondisi fungsi paru menunjukkan hasil sig. 0,40 ( $p>0,05)$ sehingga status sebaran data dikategorikan tidak normal. Kemudian dilanjutkan uji dengan Mann Whitney. Hasil uji Mann Whitney yang digunakan untuk mengetahui perbedan antara kondisi fungsi paru diperoleh nilai sig. $0,00(p<0,05)$ yang berarti berbeda signifikan antara kedua kelompok (Tabel 3).

Profil perbedaan asupan vitamin $\mathrm{C}$ antara perokok aktif dan non perokok diuji menggunakan Mann Whitney karena sebaran tidak terdistribusi normal (sig. 0,00). Hasil uji perbedaan menunjukkan hasil sig. $0,00(p<0,05)$ yang berarti terdapat perbedaan yang signifikan antara kedua kelompok. Perbedaan asupan vitamin E pada perokok dan non perokok diuji dengan Mann Whitney karena variabel asupan vitamin $\mathrm{E}$ tidak terdistribusi normal dengan nilai sig 0,002. Hasil uji Mann Whitney menunjukkan hasil sig. 0,29 ( $>>0,05)$ yang berarti tidak ada perbedaan asupan vitamin $\mathrm{E}$ antara dua kelompok (Tabel 3).

Pengaruh asupan vitamin $\mathrm{C}$ dan $\mathrm{E}$ terhadap kondisi fungsi paru dilakukan degan uji spearman. Hasil uji korelasi spearman menunjukkan bahwa terdapat hubungan yang signifikan antara asupan vitamin $\mathrm{C}$ terhadap fungsi paru $(\mathrm{r}=0,063, \mathrm{p}=0,00)$ dengan kekuatan sedang dan antara asupan vitamin $\mathrm{E}$ terhadap fungsi paru $(\mathrm{r}=0,21, \mathrm{p}=0,015)$ dengan kekuatan lemah (Tabel 4).

\section{PEMBAHASAN}

Penelitian ini memperlihatkan bahwa terdapat perbedaan yang bermakna kondisi fungsi paru antara kelompok perokok aktif dan non perokok. Asap rokok merupakan sumber radikal bebas eksogen yang menyebabkan peningkatan oksidan di dalam tubuh yang dapat mengakibatkan turunnya kapasitas paru dan iritasi pada saluran pernafasan yang menyebabkan keterbatasan aliran udara sehingga menurunkan kondisi fungsi paru. 
Hasil penelitian ini sejalan dengan penelitian yang dilakukan oleh Nawaleh et al., dan Banur et al..$^{28,29}$ Hasil penelitian menunjukkan terdapat perbedaan asupan vitamin $\mathrm{C}$ yang signifikan antara perokok aktif dan non perokok. Hasil penelitian ini sejalan dengan penelitian Ma et al. dan Jain et al. yang melaporkan perokok memiliki kebiasaan makan sumber vitamin $C$, yaitu buah dan sayur yang secara signifikan lebih rendah jika dibandingkan dengan perokok. ${ }^{30,31}$ Uji perbedaan asupan vitamin E pada perokok aktif dan non perokok menunjukkan tidak ada perbedaan yang signifikan. Hasil penelitian ini sejalan dengan penelitian yang dilakukan oleh Gabriel et al. yang meneliti asupan vitamin E di Amerika antara perokok aktif dan non perokok. $^{32}$

Adanya pengaruh asupan vitamin $\mathrm{C}$ dan $\mathrm{E}$ terhadap fungsi paru diduga karena penurunan kondisi fungsi paru terjadi karena radikal bebas dari asap rokok, sedangkan vitamin $\mathrm{C}$ dan vitamin E merupakan suatu antioksidan. ${ }^{17}$ Status antioksidan di dalam tubuh dapat ditingkatkan dengan cara mengonsumsi bahan makanan yang mengandung antioksidan tinggi. Efek antioksidan vitamin $\mathrm{C}$ yang bekerja dengan cara mendonorkan elektron yang berasal dari ikatan rangkap antara karbon kedua dan ketiganya, sehingga radikal bebas yang diberi elektron oleh vitamin $\mathrm{C}$ berubah menjadi bentuk radikal semi dehiroaskorbat atau radikal ascorbil yang tidak reaktif. Senyawa ini mudah dikeluarkan dari dalam tubuh karena mudah larut di dalam air. Vitamin E bekerja dengan cara menghentikan reaksi berantai radikal bebas dan berfungsi melindungi membran dari peroksidasi lipid. ${ }^{9,33}$ Hasil penelitian ini sesuai dengan systematic review yang dilakukan oleh Tsilligiani et al., yang menunjukkan adanya $\mathrm{FEV}_{1}$ yang lebih tinggi pada subyek dengan asupan vitamin $\mathrm{C}$ dan $\mathrm{E}$ yang lebih tinggi. ${ }^{34}$

Vitamin E banyak terdapat pada telur, ikan, udang, dan minyak. Hubungan pengaruh yang lemah antara asupan vitamin $\mathrm{E}$ terhadap fungsi paru diduga karena pada saat proses pengolahan makanan sumber vitamin $E$ tersebut diolah dengan suhu tinggi secara berulang-ulang, hal tersebut akan mengurangi konsentrasi kandungan vitamin E dan mengubah bentuk asam lemaknya, sehingga akan mengurangi efek antioksidan dari vitamin E. $35,36,37$

\section{KESIMPULAN DAN SARAN}

Terdapat perbedaan kondisi fungsi paru dan asupan Vitamin C, tetapi asupan vitamin E tidak menunjukkan perbedaan signifikan antara kelompok perokok aktif dan non perokok. Terdapat pengaruh antara asupan vitamin $\mathrm{C}$ dan $\mathrm{E}$ terhadap fungsi paru. Perlu adanya penelitian yang mengamati proses pengolahan makanan yang dikonsumsi, yang dapat mempengaruhi kandungan vitamin terkandung dalam bahan makanan.

\section{DAFTAR PUSTAKA}

1. World Health Organization. Global Adult Tobacco Survey: Indonesia Report 2011. New Delhi: World Health Organization; 2012.

2. Kemenkes RI. Riset Kesehatan Dasar 2013. Jakarta: Kementerian Kesehatan RI; 2013.

3. Lian TY dan Dorotheo U. The Tobacco Control Atlas: ASEAN Region Third Edition 2016. Bangkok: Southeast Asia Tobacco Control Alliance; 2016. 15-33.

4. Sarma AD, Mallick AR, Ghosh AK. Free Radicals and Their Role in Different Clinical Conditions: An Overview. IJPSR. 2010;1(3): 185-92.

5. Gosh M dan Ionita P. Investigation of Free Radicals in Cigarette Mainstream Smoke. MEDIMOND. 2007;49-55.

6. Joshi P, Kim WJ, dan Lee S. The Effect of Dietary Antioxidant on the COPD Risk : the Community-Based KoGES (Ansan-Anseong) Cohort. International Journal of COPD. 2015; (10): 2159-68.

7. World Health Organization. Report on the Global Tobacco Epidemic, 2011: The MPOWER Package. World Health Organization. 2011; 38-73.

8. Adegoke BO, Akinremi AA, dan Akintobi AE. Effects of Tobacco Smoking on Pulmonary Function Indices Among Undergraduate Students. Nigerian Journal of Medical Rehabilitation. 2015;18(1):1-14.

9. Nimse SB dan Pal D. Free Radicals, Natural Antioxidants, and Their Reaction Mechanisms. The Royal Society of Chemistry. 2015; (5):27986-28006.

10. Rao SP, Kalva S, Yerramilli A, et al. Free Radicals and Tissue Damage: Role of Antioxidants. Free Radicals and Antioxidants. 2011; 
1(4):1-6.

11. Lobo V, Patil A, Patak A, Chandra N. Free Radicals, Antioxidants and Functional Foods: Impact on Human Health Pharmacognosy Reviews. 2010;4(8):118-126.

12. Pham-Huy LA, He H dan Pham-Huy. Free Radicals, Antioxidants in Disease and Health. International Journal of Biomedical Science. 2008; 4(2):89-95.

13. Polidori MC, Mecocci P, Stahl W dan Sies,H. Cigarette Smoking Cessation Increases Plasma Levels of Several Antioxidant Micronutrients and Improves Resistance Towards Oxidative Challenge. British Journal of Nutrition. 2003;(90):147-50.

14. Garcia-Alonso M, Pascual-Teresa S, Santos-Buelga, C and Rivas-Gonzalo JC. Evaluation of the Antioxidant Properties of Fruits. Food Chemistry. 2004;84:13-8.

15. Schunemann H, McCann S, Grant, et al. Lung Function in Relation to Intake of Carotenoids and Other Antioxidant Vitamins in a Population-Based Study. American Journal of Epidemiology. 2002;155(5):463-71.

16. Burns JS, Dockery DW, Neas L M, et al. Low Dietary Nutrient Intakes and Respiratory Health in Adolescents. Chest Journal. 2007; 6(39):238-45.

17. Bentley AR, Kritchevsky SB, Harris TB, et al. Dietary Antioxidants and Forced Expiratory Volume in 1s Decline: the Health, Aging and Body Composition study. Eur Respir J. 2012; 39(4):979-84.

18. Russnes KM, Moller E, Kathryn M. KM, et al. Total Antioxidant Intake and Prostate Cancer in the Cancer of the Prostate in Sweden (CAPS) Study. A Case Control Ctudy. BMC Cancer. 2006;16(438):1-12.

19. Purnasari G, Briawan D, Dwiriani CM. Asupan Kalsium dan Tingkat Kecukupan Kalsium pada Ibu Hamil di Kabupaten Jember. Jurnal MKMI. 2016;12(4):261-8.

20. Tritisari KP, Handayani D, Ariestiningsih AD dan Kusumastuty I. Asupan Makanan Sumber Antioksidan Dan Kadar Glukosa Darah Puasa pada Penderita Dm Tipe 2 di Jawa Timur. Majalah Kesehatan FKUB. 2017;4(2):96-04.

21. Paulose-Ram R, Timothy Tilert T, Dillon C and Brody DC. Cigarette Smoking and Lung
Obstruction Among Adults Aged 40-79: United States, 2007-2012. National Health and Nutrition Examination. 2015.

22. Sharma MD dan Ravi R. Visual Effects of Long Term Active Smoking: Are Aircrew Flying NVG-Aided Missions at a Disadvantage?. Ind J Aerospace Med. 2010;4(1):18-5.

23. Carey MA, Card JW, Voltz JW, et al. It's all about Sex: Male-Female Differences in Lung Development and Disease. Trends Endorinol Metab. 2007;18(8):308-13.

24. Johns DP, Walters JAE, Walters EH. Diagnosis and Early Detection of COPD Using Spirometry. 2014;6(11):1557-69.

25. Ranu H, Wilde M dan Madden B. Pulmonary Function Tests. The Ulster Medical Society. 2011;80(2):84-90.

26. Quanjer PH, Pretto JJ, Brazzale DJ dan Boros PW. Grading the Severity of Airways Obstruction: New Wine in New Bottles. Eur Respir J. 2014;43:505-12.

27. Kementrian Kesehatan RI. Peraturan Menteri Kesehatan RI Nomor 75 Tahun 2003 tentang Angka Kecukupan Gizi yang Dianjurkan Bagi Bangsa Indonesia. Jakarta: Kementrian Kesehatan RI. 2014.

28. Nawaleh HA, Zead SA, Al-Maghaireh DF. Pulmonary Functiont Test: The Value among Smoker and Non Smokers. Health Science Journal. 2012;6(4):703-13.

29. Banur A, Dacosta AL, Wiseman MP, Chaudri S. A Study on Effects of Smoking on Spirometry, Thoracic Gas Volume And Residual Volume in Apparently Asymptomatic Smokers. IOSR Journal of Dental and Medical Sciences. 2016;15(12):48-54.

30. Ma J, Hampl JS, Betts NM. Antioxidant Intakes and Smoking Status: Data from the Continuing Survey of Food Intakes by Individuals 1994-1996. Am J Clin Nutr. 2000;71(3):77480.

31. Jain A, Agrawal BK, Varma M, dan Jadhav AA. Antioxidant Status and Smoking Habits: Relationship with Diet. Singapore Med J. 2009;50(6):624-7.

32. Gabriel HE, Liu Z, Crott JW, et al. A Comparison of Carotenoids, Retinoids, and Tocopherols in the Serum and Bucal Mucosa of Chronic Cigarette Smokers versus Nonsmokers. Amer- 
ican Association for Cancer Research. 73:62532.

33. Padayatty SJ, Katz A, Wang Y, et al. Vitamin $\mathrm{C}$ as an Antioxidant: Evaluation of Its Role in Disease Prevention. Journal Of The American College Of Nutrition. 2003;22(1):18-35.

34. Tsiligiani IG dan Molen T. A Systematic Review of the Role of Vitamin Insufficiencies and Supplementation in COPD. Respiratory Research. 2010;11(171):1-8.

35. Jaarin K dan Kamsiah Y. Repeatedly Heated
Vegetable Oils and Lipid Peroxidation. Intech. 2012; 211-27.

36. Yuniati $\mathrm{H}$ dan Almasyhuri. Kandungan Vita$\min \mathrm{B}_{6}, \mathrm{~B}_{9}, \mathrm{~B}_{12}$ dan E Beberapa Jenis Da-ging, Telur, Ikan dan Udang Laut di Bogor dan Sekitarnya. Penel Gizi Makan. 2012;35(1):78-89.

37. Leong XF, Ng CY, Jaarin K dan Mustafa MR. Effects of Repeated Heating of Cooking Oils on Antioxidant Content and Endothelial Function. Austin Journal of Pharmacology and Therapeutics. 2015;3(2):1-7. 